\title{
Frequency of Night B lindness in Cirrhosis and Effective Restoration of Vision with Vitamin a Therapy
}

\author{
M. Q asim Rahopoto, Suhail A. Almani, Muzaffar A. Shaikh, M. Iqbal Shah, Narinder \\ Maheshwari, Ghulam H ussain Baloch and Kumar Lal
}

\begin{abstract}
OBJECTIVE: To determine the frequency of night blindness among cirrhotic patients and evaluate the restoration of vision with vitamin A therapy.

DESIGN: - Case-control observational study.

SETTING: Medical ward of Liaquat University Hospital Hyderabad / Jamshoro, Sindh - Pakistan; from January 2006 to December 2007.

METHODS: Two hundred cirrhotic patients admitted at medical unit IV were enrolled in the study. The non-cirrhotic patients were excluded. Fifty healthy volunteers took part as the control subjects.

RESULTS: Out of 200 patient, 116(58\%) were males and 84(42\%) females. The mean age of the cirrhotic patients was $48.46 \pm 11.97$ years. The cause of cirrhosis was hepatitis $C$ virus in 146 (73\%) cases, hepatitis B virus in $19(9.5 \%)$ cases, hepatitis C and B virus in $7(3.5 \%)$ cases, non B and $C$ virus in $24(12 \%)$ cases and alcohol in $4(2 \%)$ cases. When cirrhotic patients were grouped into Child-Pugh's score, $44(22 \%)$ were in class A, $106(53 \%)$ in class B and $50(25 \%)$ in class C. Among 200 patients, $122(61 \%)$ had history of night blindness and 25(12.5\%) had the colour blindness. Restoration of vision was observed in $105(86 \%)$ patients with vitamin A therapy (tablet Vitamin A 50,000 IU, Wilson Pharma), twice daily, for 6 weeks time.

CONCLUSION: The history of night blindness and its restoration of vision with vitamin $A$ therapy is a rough indicator of vitamin A deficiency in cirrhotic patients. The larger studies are required especially RBP (plasma retinol binding protein) and serum vitamin A concentration before recommendation of vitamin A replacement. The Ophthalmic changes in cirrhotic patients are preventable and treatable.
\end{abstract}

KEY WORDS: Cirrhosis. Night Blindness. Child-Pugh's Class. Vitamin A.

\section{INTRODUCTION}

The liver consists of several cell types, of which two hepatocytes; parenchymal cell and stellate cell are directly involved in the metabolism of vitamin A. ${ }^{1}$ Vitamin A participates in several biological mechanisms, as epithelial differentiation, gene expression, reproduction, normal vision and integrity of the immune system. ${ }^{2}$ The liver plays a central role in the uptake, storage and is also the oxidation site of vitamin A catabolism and responsible for the regulated release of this Vitamin A to other tissue. ${ }^{3}$ In liver parenchymal cells, the retinyl esters are hydrolyzed and the free retinol is bound to cellular retinol protein (CRPB1) and then transferred to the stellate cells; also called lipocytes, fat storing cells or Ito cells. ${ }^{4}$ Vitamin A is transported to the tissues in the form of retinol bound to retinol binding proteins (RBP) in a l:I complex. Normally, 95\% of vitamin A circulating in the plasma comprises of retinol bound to RBP, and the remaining 5\% constitutes retinol esters in chylomicrons. Plasma vitamin A levels are largely regulated by the production and turn over rate of RBP. Plasma RBP is measured by radial immuno-diffusion highly correlate with plasma retinol. ${ }^{5}$ Plasma RBP has 93\% sensitivity for predicting marginal vitamin A status and $91 \%$ sensitivity for predicting vitamin A deficiency; the corresponding specificities are $75 \%$ and $94 \%$ respectively. ${ }^{6}$ The Ophthalmic pathologies of cirrhosis in the literature involve xerophthalmia, Vitamin A deficiency and color blindness. Xerophthalmia and keratoconjuctivitis observed in Sjoqren's syndrome may be associated with autoimmune hepatitis and primary biliary cirrhosis. Xerophthalmia is also observed in vitamin A deficiency. It may even progress to small greyish lesion namely Bitot's spots and night blindness may ensue. Vitamin A deficiency may be seen in cirrhosis, since liver is the organ where vitamin A is deposited. ${ }^{7}$ Liver injury secondary 
to chronic hepatitis B virus (HBV) ${ }^{8}$ and chronic hepatitis $\mathrm{C}$ virus (HCV). ${ }^{9}$ Alcoholic liver disease is one of the most common causes of the liver cirrhosis and it is among ten most common causes of liver cirrhosis in the world. ${ }^{10}$ Alcoholic liver disease has a wide clinical spectrum, it may progress to cirrhosis and to end stage liver disease. ${ }^{11}$

\section{PATIENTS AND METHODS}

This study was conducted at Liaquat University Hospital Hyderabad/Jamshoro. Two hundred cirrhotic patients admitted at Medical unit IV of hospital from January 2006 to December 2007 were enrolled in this study. The control group comprised of 50 healthy volunteers; none of them had a history of DM, hypertension, liver disease and alcohol consumption. They were also not having any drug related disorders. All patients had clinical, laboratory and ultrasonographic features compatible with cirrhosis. Patients were observed clinically (portal hypertension, ascites, varices, luconychia, palmar erythemia, gynecomastia, spider navi, testicular atrophy, etc.) as well as laboratory findings (decreased total protein, low serum albumin, high globulin, altered $A / G$ ratio and liver function test L.F.T). The ultrasound examination revealed small size of the liver with increased echogenicity, dilated portal vein $>1.4 \mathrm{~cm}$, splenomegaly and ascites. Patients were also classified according to Child-Pugh's classification. The Child-Pugh's classification has been designed to assess the prognosis of patients with cirrhosis of liver. The $P$ value $\leq 0.05$ was considered statistically significant. Statistical analysis was performed using SPSS version 14.0.

\section{RESULTS}

Out of 200 patients, $116(58 \%)$ were males and 84 (42\%) females (Table I). The mean age of the cirrhotic patients was $48.46 \pm 11.97$ years. The cause of cirrhosis was hepatitis $C$ virus in $146(73 \%)$ patients, hepatitis $B$ virus in $19(9.5 \%)$, hepatitis $C$ and $B$ virus in $7(3.5 \%)$ patients, non B and non $C$ virus in $24(12 \%)$ patients and alcohol in $4(2 \%)$ patients. Among these cirrhotic patients, there were $44(22 \%)$ in Child Pugh Class A, 106 (53) in Child-Pugh's Class B and 50 (25\%) in Child Pugh Class C. Out of 200 patients, 122 (61\%) had history of night blindness and 25(12.5\%) patients had the colour blindness. Vitamin A replacement therapy (tablet Vitamin A 50,000 IU, Wilson Pharma), twice daily for 6 weeks showed clinical improvement in $105(86 \%)$ cases.
TABLE I:

\section{DEMOGRAPHIC CHARACTERISTICS AMONG BOTH GROUPS $(n=250)$}

\begin{tabular}{|l|c|c|c|}
\hline $\begin{array}{l}\text { Charac- } \\
\text { teristics }\end{array}$ & $\begin{array}{c}\text { Cases } \\
(\mathbf{n}=\mathbf{2 0 0})\end{array}$ & $\begin{array}{c}\text { Controls } \\
(\mathbf{n}=\mathbf{5 0})\end{array}$ & $\mathbf{P}$ value \\
\hline $\begin{array}{l}\text { Age } \\
\text { (in years) }\end{array}$ & $48.46 \pm 11.97$ & $39.20 \pm 7.12$ & $<0.001^{*}$ \\
\hline BMI & $24.25 \pm 3.88$ & $22.65 \pm 2.92$ & 0.007 \\
\hline $\begin{array}{l}\text { Sex } \\
\text { Male } \\
\text { Female }\end{array}$ & $\begin{array}{c}116(58.0 \%) \\
84(42.0 \%)\end{array}$ & $\begin{array}{l}33(66.0 \%) \\
17(34.0 \%)\end{array}$ & 0.30 \\
\hline
\end{tabular}

Results are presented as Mean \pm Standard Deviation ${ }^{*} P$ value is highly significant

\section{TABLE II:}

ETIOLOGY OF CIRRHOSIS $(n=200)$

\begin{tabular}{|c|c|}
\hline Serology & $\mathbf{n}(\%)$ \\
\hline HCV & $146(73)$ \\
HBV & $19(9.5)$ \\
HCV+HBV & $7(3.5)$ \\
NBNC & $24(12)$ \\
Alcohol & $4(2)$ \\
Others & 0 \\
\hline Child-Pugh's Class: \\
\hline C \\
B & $50(25)$ \\
A & $106(53)$ \\
\hline
\end{tabular}

TABLE III:

NIGHT COLOUR BLINDNESS $(n=250)$

\begin{tabular}{|c|c|c|c|}
\hline & $\begin{array}{c}\text { Cases } \\
(n=200)\end{array}$ & $\begin{array}{l}\text { Controls } \\
(n=50)\end{array}$ & $P$ value \\
\hline $\begin{array}{l}\text { Night } \\
\text { Blindness } \\
\text { Yes } \\
\text { No }\end{array}$ & $\begin{array}{c}122(61.0 \%) \\
78(39.0 \%)\end{array}$ & $\begin{array}{c}0 \\
50(100.0 \%)\end{array}$ & $<0.001^{*}$ \\
\hline $\begin{array}{l}\text { Colour } \\
\text { Blindness } \\
\text { Yes } \\
\text { No }\end{array}$ & $\begin{array}{c}25(12.5 \%) \\
175(87.5 \%)\end{array}$ & $\begin{array}{c}0 \\
50(100.0 \%)\end{array}$ & $0.008^{*}$ \\
\hline
\end{tabular}

${ }^{*} P$ value is statistically significant

\section{DISCUSSION}

The topic studied is unique, on which few studies are conducted in past 3 decades. The available literature on this topic is minimal which shows the importance of this research work. Chronic HCV infection was found 
most prevalent cause of liver cirrhosis followed by chronic HBV, alcohol, and PBC reflecting the overall prevalence of these etiological causes of cirrhosis of liver in this part of the world. ${ }^{12}$ In this study, we observed that males are more victim of cirrhosis. Hepatitis C virus in 146(73\%) cases and Hepatitis B virus 19 $(9.5 \%)$ were the major cause of cirrhosis in this study. The frequency of night blindness was 122(61\%) and colour blindness in $25(12.5 \%)$ cases. The restoration of vision with Vitamin A replacement therapy was observed in $86 \%$ cases, whereas in control group, neither a single case of night blindness nor colour blindness was observed. Furthermore, there is a statistically significant difference between two groups. The cirrhosis of liver in itself is well known to cause malnutrition and malabsorption especially of fat soluble vitamins and also reduce the capacity of liver to store these vitamins. ${ }^{13}$ Decreased storage of vitamin $\mathrm{A}$ in the liver and its malabsorption are responsible for deficiency of vitamin A in cirrhosis. Colour blindness is more common in alcoholic type of cirrhosis. ${ }^{14}$ In the absence of zinc deficiency or severe protein deficiency, dark adaptation is a reliable and highly reproducible functional indicator of Vitamin A nutritional status, however it is reported that abnormal dark adaptation can occur over a fairly wide range of serum vitamin A concentration in clinical population. ${ }^{15}$ Night blindness is a common finding in cirrhosis of liver and its relationship to plasma vitamin A level has not been studied extensively. Study conducted by Ukleja et al., although found low serum concentration of retinol in cirrhotic patients, did not find a significant difference in serum vitamin A concentration in those having symptoms of night blindness and those without. However, total hepatic vitamin A levels were significantly lower in patients with symptoms of night blindness than in those without, again proving the association between vitamin A deficiency and night blindness. ${ }^{16}$ On the contrary, another study conducted by Mahmood $\mathrm{K}$ et al, serum retinol binding protein as an indicator of vitamin A status in cirrhotic patients with night blindness showed that serum RBP levels were low in $44 \%$ patients, proving the fact that RBP and vitamin A deficiency are common in cirrhotic patients, however this study shows night blindness clinically in $61 \%$ cirrhotic patients. ${ }^{17}$

\section{CONCLUSION}

The night blindness and its restoration with vitamin A therapy is a rough indicator of vitamin A deficiency in cirrhotic patients. Larger studies are required especially plasma RBP and serum vitamin A level before recommendation of vitamin A replacement. The ophthalmologic changes in cirrhotic patients are preventable and treatable.

\section{REFERENCES}

1. Blomhoff R. Transport and metabolism of vitamin A. Nutr Rev. 1994; 52(2): S13-23.

2. Goodman DS. Vitamin $A$ and retinoids in health and disease. N Engl J Med. 1984; 310(16): 102331.

3. Hendriks HF, Bosma A, Brouwer A. Fat-storing cells: hyper- and hypovitaminosis $A$ and the relationships with liver fibrosis. Semin Liver Dis. 1993; 13(1): 72-80.

4. Quadro L, Hamberger L, Colantuoni V, Gottesman $\mathrm{ME}$, Blaner WS. Understanding the physiological role of retinol-binding protein in vitamin A metabolism using transgenic and knock out mouse models. Mol Aspects Med. 2003; 24(6):421-30.

5. Almekinder J, Manda W, Soko D, Lan Y, Hoover DR, Semba RD. Evaluation of plasma retinolbinding protein as a surrogate measure for plasma retinol concentrations. Scand J Clin Lab Invest. 2000; 60:199-203.

6. Baeten JM, Richardson BA, Bankson DD, Wener $\mathrm{MH}$, Kreiss JK, Lavreys $\mathrm{L}$, et al. Use of serum retinol-binding protein for prediction of vitamin A deficiency: Effects of HIV-1 infection, protein malnutrition and the acute phase response. Am J Clin Nutr. 2004; 79:218-25.

7. Ettl A, Daxecker F. Xerophthalmia in liver cirrhosis. Correct diagnosis after 15 years. Ophthalmologica. 1992; 204: 63-66.

8. Abbas Z, Jafri, Shah SH, Khokhar N, Zuberi SJ. Pakistan Society of Gestroenterology and GI Endoscopy: PGS consensus statement on management of hepatitis B virus infection. 2003. J Pak Med Assoc. 2004; 54: 150-8.

9. Hamid S, Umer M, Aslam A, Siddique A, Qureshi $\mathrm{H}$, Butt $\mathrm{J}$, et al. PGS consensus statement on management of hepatitis $C$ virus infection-2003. J Pak Med Assoc. 2004; 54:145-50.

10. Stewart SF, Day CP. The management of alcoholic liver disease. J Hepatol. 2003; 38(Suppl 1):S2-13.

11. Mendez Sanchez N. Alcoholic liver disease. An update. Ann Hepatol. 2005; 4(1):32-42.

12. Vaiphei K, Pal NS, Arora SK. Comparative analysis of HBV and HCV infection in hepatocellular carcinoma and chronic liver disease: an autopsy based study. Indian J Pathol Microbiol. 2006;49:357-61. 
13. Underwood BA. Vitamin $A$ in animal and human nutrition. In: Sporn MB, Roberts $A B$, Goodman DS, eds. The Retinoids, Vol 1. Orlando, Academic Press; 1984: 281-392.

14. Onder C, Bengur T, Selcuk D, Balents, Bellcis U, Ahmet $\mathrm{M}$, et al. Relationship between retinopathy and cirrhosis. World J Gastroenterol. 2005; 11:2193-6.

15. Carney EA, Russell RM. Correlation of dark adaptation test results with serum vitamin A levels in diseased adults. J Nutr. 1980; 110:552.
16. Ukleja A, Scolapio JS, McConnell JP, Spivey JR, Dickson RC, Nguyen JH, et al. Nutrition assessment of serum and hepatic vitamin A levels in patients with cirrhosis. JPEN J Parenter Enteral Nutr. 2002; 26:184-8.

17. Mahmood K, Samo AH, Jairamani KL, Ali G, Talib A, Qazmi W. Serum retinol binding protein as an indicator of vitamin A status in cirrhotic patients with night blindness. Saudi J Gastroenterol. 2008; 14:7-11.

AUTHOR AFFILIATION:

Dr. M. Qasim Rahopoto (Corresponding Author)

Assistant Professor, Department of Medicine

Liaquat University of Medical \& Health Sciences

(LUMHS) Jamshoro, Sindh - Pakistan.

Email:unlettered@gmail.com

\section{Dr. Suhail A. Almani}

Associate Professor, Department of Medicine LUMHS Jamshoro, Sindh - Pakistan.

\section{Dr. Muzaffar A. Shaikh}

Assistant Professor, Department of Medicine

LUMHS Jamshoro, Sindh - Pakistan.

\section{Dr. M. Iqbal Shah}

Senior Registrar, Department of Medicine

LUMHS Jamshoro, Sindh - Pakistan

\section{Dr. Narinder Maheshwari}

Department of Medicine

LUMHS Jamshoro, Sindh - Pakistan

\section{Dr. Ghulam Hussain Baloch}

Senior Registrar, Department of Medicine

LUMHS Jamshoro, Sindh - Pakistan

\section{Dr. Kumar Lal}

Department of Medicine

LUMHS Jamshoro, Sindh - Pakistan 